\title{
Neolocalization in the Neoesophagus: Presternal Transposition
}

\section{Neoözofagusta Neolokalizasyon: Presternal Transpozisyon}

\author{
Murat Cakir ${ }^{1}$, Mehmet Bicer ${ }^{1}$
}

${ }^{1}$ Necmettin Erbakan University, Meram Faculty of Medicine, Department of General Surgery, Konya, Turkey

Address correspondence to: Murat Cakir, Necmettin Erbakan University, Meram Faculty of Medicine, Department of General Surgery, Konya, Turkey

e-mail:drmuratcakir@hotmail.com

Geliş Tarihi/Received: 2 September 2021 Kabul Tarihi/Accepted: 30 November 2021

\section{Öz}

Erken evre distal özofagus kanserleri ve proksimal mide kanserlerinde en yaygın tedavi yöntemi cerrahidir. Özofagus cerrahisinin zorluklarından biri gastrointestinal devamlılığının sağlanmasıdır. Bu amaçla mide, ince barsak ve kolon kullanılabilir. Neoözofagus posterior mediastinal veya retrosternal alandan servikal bölgeye ulaştırılır. Distal özofagus kanseri nedeniyle opere edilip özofagusu güdük halinde bırakılan hastanın yapılan presternal kolonik transpozisyonu literatür eşliğinde tartışılması amaçlandı. 61 yaşında erkek hasta, özofagus ca nedeniyle transhiatal olarak total gastrektomi ve distal özofajektomi cerrahis uygulanmış. Anastomoz kaçağı nedeniyle sağ torakotomi yapılmış ve özofagus güdük olarak bırakılmış. Beslenme jejunostomisi açılmış. Akciğer metastazı nedeniyle sol torakotomi ile metastazektomi yapılmış. Rekonstruksiyon amaçla sol kolon presternal alandan ilerletilerek servikal bölgeye ulaştırılarak özofagus amastomozu yapıldı. Özofagus cerrahisinde konduitin lokalizasyonunda son çare olarak presternal alanda ilerletilmesi akılda tutulmalıdır.

Anahtar Kelimeler: Neoözofagus, neolokalizasyon, presternal

\section{Abstract}

The most common therapeutic method for early stage distal esophageal cancers and proximal stomach cancer is surgery. One of the challenges in esophageal surgery is to maintain gastrointestinal continuity. The neoesophagus is transferred from the posterior, mediastinal, or retrosternal areas to the cervical region. A 61-year-old male patient with esophageal cancer had received transhiatal total gastrectomy, distal esophagectomy, and Roux-en-Y esophagojejunostomy. Right thoracotomy had been performed due to anastomotic leak with the esophageal stump left behind. Left thoracotomy and metastasectomy were also performed due to lung metastasis. The left colon was transpositioned from the presternal area to the cervical region for reconstructive purposes. Physicians should bear in mind that the conduit can be advanced in the presternal area as the last resort for its localization in esophageal surgery. The aim of this study was to present, along with literature review, the case of a patient with distal esophageal cancer for whom presternal colonic transposition was performed with the esophageal stump left behind.

Key words: Neoesophagus, neolocalization, presternal

Cite this article as: Cakir M, Bicer M. Neolocalization in the Neoesophagus: Presternal Transposition. Selcuk Med J 2021;37(4): 371-374

"This article is licensed under a Creative Commons Attribution-NonCommercial 4.0 International License (CC BY-NC 4.0)"
Disclosure: None of the authors has a financial interest in any of the products, devices, or drugs mentioned in this article. The research was not sponsored by an outside organization. All authors have agreed to allow full access to the primary data and to allow the journal to review the data if requested. 


\section{INTRODUCTION}

The most common therapeutic method for early stage distal esophageal cancers and proximal stomach cancer is surgery (1). Surgical methods to this end include transhiatal, transthoracic or combined approaches. Transhiatal interventions are usually preferred in patients to receive distal esophagectomy. Yet surgeons opt for combined approaches more in patients to receive subtotal esophagectomy or total esophagectomy. Post-esophagectomy reconstruction is important. One of the most challenging parts of esophageal surgery is to maintain gastrointestinal continuity. The stomach, small intestine and the colon can be utilized to this end1.

The mortality and morbidity rates in esophageal surgery are quite high. The most common and fatal complications within this scope are pulmonary problems and anastomotic leaks (2). Anastomotic leaks are the most feared and hardest-to-manage complications in esophageal surgery $(2,3)$. The esophagus can be left in the form of salivary fistula or of stump in cases where the continuity of the digestive system cannot be maintained following anastomotic leaks (4). Such cases render reconstructive processes hard and complicated.

Presternal colonic transposition performed in a patient with distal esophageal cancer, whose esophageal stump was left behind following an anastomotic leak, was discussed in light of literature.

\section{CASE}

The 61-year-old male patient had received transhiatal total gastrectomy, distal esophagectomy and Roux-en-Y esophagojejunostomy because of esophageal cancer at an external center. The patient had been re-operated upon post-operative anastomotic leak development. He had received right thoracotomy when the anastomotic area could not be reached through the transhiatal approach. Ischemia and split had been observed in the anastomotic area. After the re-resection of the esophagus, it had been seen that the jejunal loop was too short to reconstruct. Then feeding jejunostomy had been opened up with the esophagus closed at the carinal level and the stump was left behind. Following a two-month intensive care treatment, the patient was referred to our center in order to sustain gastrointestinal continuity. The initial evaluation of the patient revealed intensive intraabdominal inflammation and metastasis in the lung. Left thoracotomy and metastasectomy were performed for the patient following oncologic

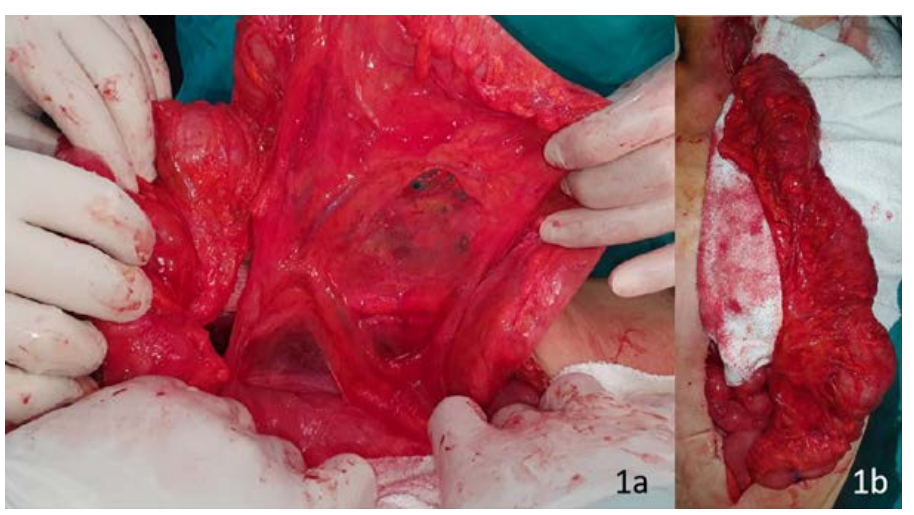

Figure 1. Conduit preparation (2a: identification of vascular structures, $2 \mathrm{~b}$ : creation of the conduit)

treatment. The patient was evaluated for intestinal continuity following oncologic treatment as well. Colonic transposition was subsequently planned for the patient. It was, however, decided to advance the colon over the sternum because of right and left thoracotomy and transhiatal interventions. The patient was taken into surgery after preoperative preparations. The left colon was prepared during the surgery (Figure 1a-1b). The esophagus was suspended through the cervical approach. A tunnel was formed from the subcutaneous area over the



Figure 2. Trochal preparation (3a: creation of the presternal tunnel, $3 \mathrm{~b}$ : advancing the conduit) 


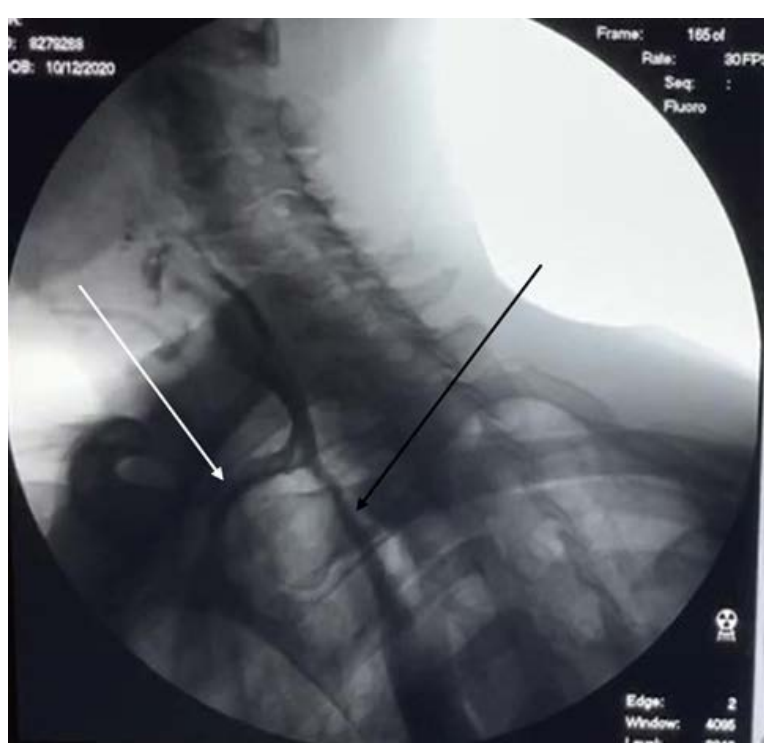

Figure 3. Evaluation with passage radiography (white arrow: contrast material in the colon, black arrow: contrast material accumulated in the truncated esophagus)

sternum. The colon was advanced along the newly formed tunnel (Figure 2a-2b) while anastomosis was created with circular stapler of no. 28 in the cervical region. Leakage test was performed with methylene blue on the 5th post-operative day. The patient was started on oral intake upon no leakage was seen. Three days after the initiation of oral intake, however, leakage was identified and oral intake was stopped. Total parenteral feeding was started. As there was no salivary leak from the anastomotic line, the patient was given water-soluble contrast material 15 days later and passage radiography was performed (Figure 3 ). Oral feeding was started. The patient was discharged on the 45th day since he had no problems following oral intake.

\section{DISCUSSION}

Post-esophagectomy complications may develop in patients at a rate between $20 \%$ and $80 \%$. These complications may be systemic (pulmonary or myocardial) or surgery-specific (anastomotic leak, recurrent laryngeal damage and the like) (5). Although pulmonary complications are frequently seen, anastomotic leak is the most feared complication (6). The rate of anastomotic leaks go as high as $40 \%$. Both anastomotic leak and pulmonary complications were seen in our patient in the initial post-operative period.
One of the complications that we feared most while we prepared our patient for surgery was pulmonary complication. Therefore a surgical method without thoracotomy was planned. The patient developed no pulmonary complications following the surgery performed at our clinic since thoracotomy was not performed. Although the cosmetic result was poor, the patient did not experience any problems regarding functional results (difficulty in swallowing).

The conduit used for reconstruction is usually the stomach. The colon, however, can be utilized as a secondary option. Non-gastric neoesophagi are not generally preferred unless they are necessary. The neoesophagus is transferred to the posterior, mediastinal or retrosternal cervical region (7). These positions bear no superiority to one another. We did, however, advance the neoesophagus from the presternal area in our patient because we thought that surgery would be harder in these areas due to thoracotomy. We had nothing but the colon since the patient's stomach and small intestines had been used. We used the left colon particularly because it had less vascular malformation, was longer, and similar in diameter to the esophagus.

Anastomotic leak-related mortality rates vary between $2 \%$ and $12 \%$ (8). There are many factors that bring about leakage. Anastomotic factors, localization of the anastomoses, conduit type and the localization of conduits are the most common causing factors (9). Other than these, conduit ischemia, neoadjuvant therapy and comorbidity prove to be the other causing factors. Our patient had many risk factors. The conduit option was the risky colon, while the conduit localization was the presternal area which is hardly ever a localization of choice. Our patient was a vulnerable one who had received chemotherapy before the operation and had thoracotomy twice with subsequent anastomotic leak. We preferred this method in order to minimize surgical morbidity and mortality, and succeeded. We observed a partial anastomotic leak for a short time which then spontaneously closed up.

In conclusion, physicians should take into account that the presternal area proves to be an option as a last resort in the localization of the conduit in esophageal surgery that has high mortality and morbidity rates.

Conflict of interest: Authors declare that there is no conflict of interest between the authors of the article.

Financial conflict of interest: Authors declare that they did not receive any financial support in this study. 
Address correspondence to: Murat Cakir, Necmettin Erbakan University, Meram Faculty of Medicine, Department of General Surgery, Konya, Turkey.

e-mail:drmuratcakir@hotmail.com

\section{REFERENCES}

1. Rustgi AK, El-Serag HB: Esophageal carcinoma. N Engl J Med 2014;371:2499-509.

2. Biere SS, Maas KW, Cuesta MA, et al. Cervical or thoracic anastomosis after esophagectomy for cancer: A systematic review and meta-analysis. Dig Surg 2011;28(1):29-35.

3. Price TN, Nichols FC, Harmsen WS, et al. A comprehensive review of anastomotic technique in 432 esophagectomies. Ann Thorac Surg 2013;95(4):1154-61.

4. Bakshi A, Sugarbaker DJ, Burt BM. Alternative conduits for esophageal replacement. Ann Cardiothorac Surg 2017;6(2):137-43.

5. Morita M, Nakanoko T, Fujinaka Y, et al. In-hospital mortality after a surgical resection for esophageal cancer: Analyses of the associated factors and historical changes. Ann Surg Oncol 2011;18(6):1757-64.
6. Saluja SS, Ray S, Pal S, et al. Randomized trial comparing side-to-side stapled and hand-sewn esophagogastric anastomosis in neck. J Gastrointest Surg 2012;16(7):128794.

7. Orringer MB, Marshall B, Chang AC, et al. Two thousand transhiatal esophagectomies: Changing trends, lessons learned. Ann Surg 2007;246(3):363-72; discussion 372-4.

8. Ölmez Ş, Sarıtaş B, Kara B, et al. Treatment of esophageal strictures with savary-guilliard bougies. Dicle Med J 2017;44(2):145-50.

9. Briel JW, Tamhankar AP, Hagen JA, et al. Prevalence and risk factors for ischemia, leak, and stricture of esophageal anastomosis: Gastric pull-up versus colon interposition. J Am Coll Surg 2004;198(4):536-41; discussion 541-2. 